Section Editor

John J. Millichap, MD

Teaching NeuroImages:

\title{
Takayasu arteritis
}

Neuroimaging progression after immunosuppressant treatment

Laura Martínez

Rodríguez, MD

Luis Caminal Montero, MD

Jorge Peña Suarez, MD

Carmen Garcia-Cabo

Fernández, MD

Sergio Calleja Puerta,

$\mathrm{PhD}, \mathrm{MD}$

Correspondence to

Dr. Martínez Rodríguez:

lauramartinezrodriguez88@gmail.

com

Download teaching slides: Neurology.org

Figure 13 3D magnetic resonance (MR) angiographic multiplanar reconstruction: Pre and post immunosuppressant treatment vertebral artery (VA)
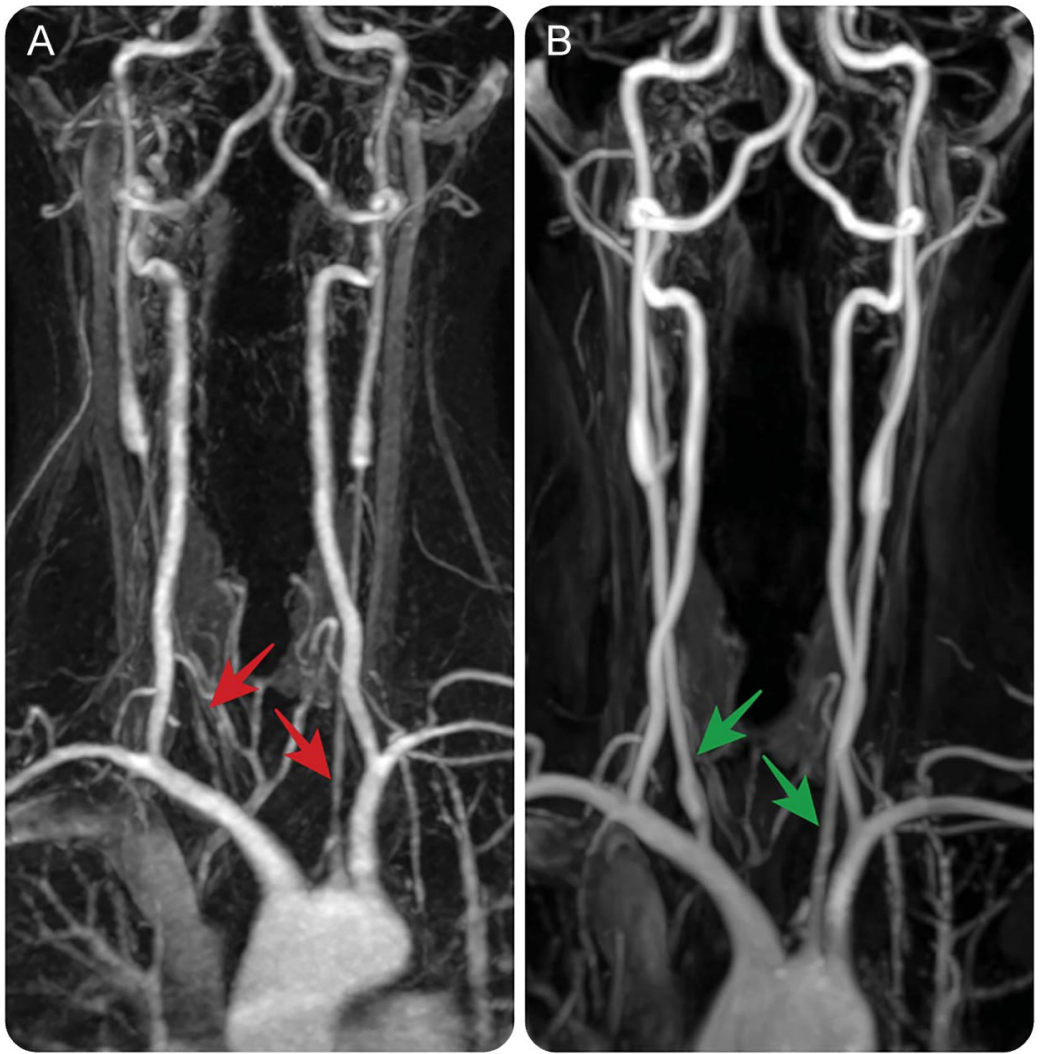

(A) Severe stenosis in VA origin (red arrows). (B) Mild luminal narrowing of proximal diameter in VA (green arrows).

A 29-year-old woman presented with a 2-year history of heel pain, constitutional symptoms, and increased acute phase reactants. CT and magnetic resonance (MR) angiography revealed a thickening of aortic walls and a thread-like appearance of bilateral subclavian and common carotid arteries. The findings were consistent with Takayasu arteritis (TA) ${ }^{1}$ and the patient was prescribed methylprednisolone, followed by azathioprine. Follow-up MR angiography, 6 years later, showed an important improvement with only a mild luminal narrowing of both common carotid arteries (figures 1 and 2, A and B). TA is a large-artery inflammatory disease of unknown etiology. MRI findings parallel clinical and serologic improvement during follow-up.

\section{AUTHOR CONTRIBUTIONS}

Laura Martínez Rodríguez: original idea and drafting content. Luis Caminal Montero: acquisition of data. Carmen Garcia-Cabo Fernandez: collection of information. Jorge Peña Suarez: image editing. Sergio Calleja Puerta: study supervision.

\section{STUDY FUNDING}

No targeted funding reported.

\section{DISCLOSURE}

The authors report no disclosures relevant to the manuscript. Go to Neurology.org for full disclosures.

\section{REFERENCE}

1. Serra R, Butrico L, Fugetto F, et al. Updates in pathophysiology, diagnosis and management of Takayasu arteritis. Ann Vasc Surg 2016;35:210-225.

From the Neurology Department (L.M.R., C.G.-C.F., S.C.P.), Internal Medicine Department (L.C.M.), and Radiology Department (J.P.S.), Hospital Universitario Central de Asturias, Oviedo, Asturias, Spain. 
Figure 2 3D magnetic resonance (MR) angiographic multiplanar reconstruction: Improvement of distal thickness of the common carotid artery

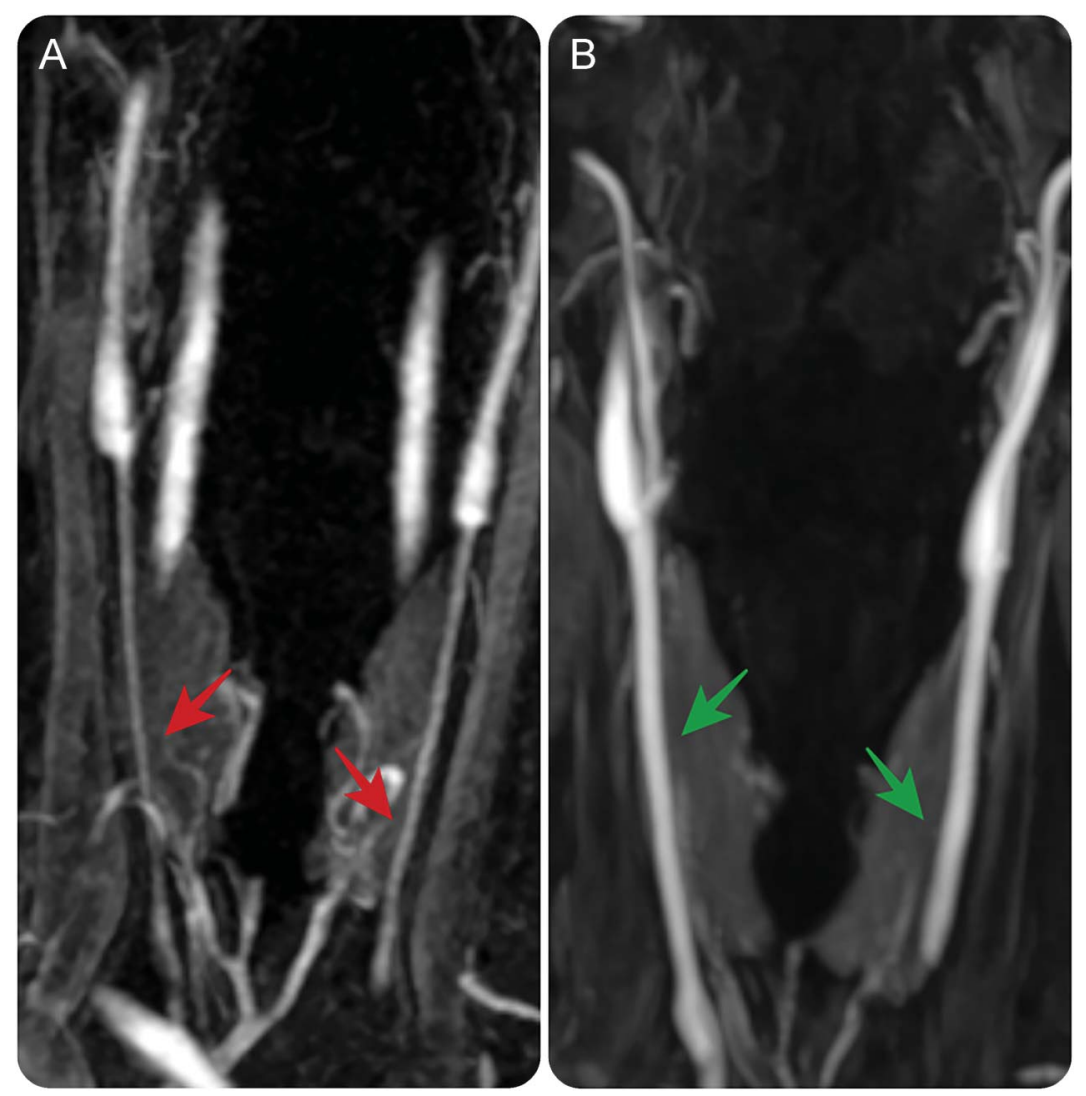

(A) Before treatment with immunosuppressants (red arrows). (B) After 6 years of immunosuppressive therapy (green arrows). 


\section{Neurology}

\section{Teaching NeuroImages: Takayasu arteritis: Neuroimaging progression after immunosuppressant treatment \\ Laura Martínez Rodríguez, Luis Caminal Montero, Jorge Peña Suarez, et al.}

Neurology 2017;88;e192-e193

DOI 10.1212/WNL.0000000000003939

\section{This information is current as of May 15, 2017}

\section{Updated Information \& Services}

\section{Supplementary Material}

\section{References}

Subspecialty Collections

Permissions \& Licensing

\section{Reprints}

including high resolution figures, can be found at: http://n.neurology.org/content/88/20/e192.full

Supplementary material can be found at: http://n.neurology.org/content/suppl/2017/05/16/WNL.0000000000003 939.DC1

This article cites 1 articles, 0 of which you can access for free at: http://n.neurology.org/content/88/20/e192.full\#ref-list-1

This article, along with others on similar topics, appears in the following collection(s):

All Cerebrovascular disease/Stroke

http://n.neurology.org/cgi/collection/all_cerebrovascular_disease_strok e

MRI

http://n.neurology.org/cgi/collection/mri

Vasculitis

http://n.neurology.org/cgi/collection/vasculitis

Information about reproducing this article in parts (figures,tables) or in its entirety can be found online at:

http://www.neurology.org/about/about_the_journal\#permissions

Information about ordering reprints can be found online: http://n.neurology.org/subscribers/advertise

Neurology ${ }^{\circledR}$ is the official journal of the American Academy of Neurology. Published continuously since 1951, it is now a weekly with 48 issues per year. Copyright @ 2017 American Academy of Neurology. All rights reserved. Print ISSN: 0028-3878. Online ISSN: 1526-632X.

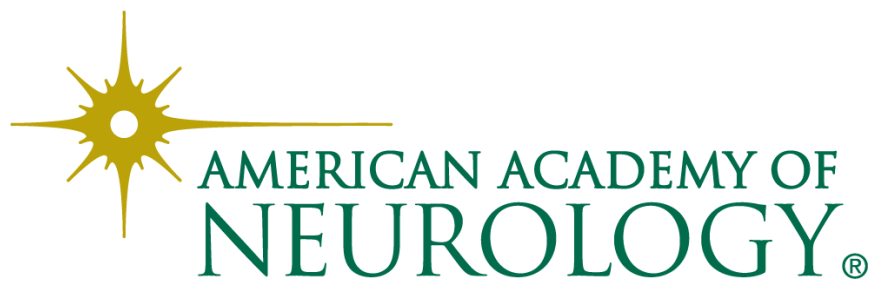

